\title{
Caught between Human Right Abuse and Survival: The Incidence of Child Labour in Obuasi
}

\author{
Abena Oforiwaa Ampomah \\ Charles Gyan \\ Department of Social Work, Faculty of Social Sciences, University of Ghana, \\ P. O. Box LG419, Legon-Accra, Ghana
}

\section{Doi:10.5901/ajis.2014.v3n1p73}

\begin{abstract}
Children who are the future leaders of countries are exploited and forced into labour instead of receiving good education. Despite the increasing commitment by governments and their partners to tackle child labour worldwide, it remains a problem on the massive scale. This study therefore seeks to assess the effects of child labour on children with specific emphasis on the Obuasi municipality of the Ashanti region of Ghana. The study adopted the use of the mixed research method. Purposive sampling technique was used to select respondents for the study. The sample size for this study was fifty (50) people. The study reveals that children engaged in galamsey to contribute to their family income, to pay their school fees and to provide for themselves basic needs such as food, clothing, and shelter. Also, it is evident that the children's involvement in this activity has affected them adversely. From the study it is clear that child labour negatively affects the education of children. Based on these findings the study recommends joint efforts among various stakeholders with the aim of developing public awareness of children's rights and the problems encountered by working children.
\end{abstract}

Keywords: Child labour, Galamsey, academic achievement, mining

\section{Introduction}

Child labour has been defined by most authors as the involvement of children in work that affect their health and education (Schrumpf, 2004; Kielland \& Tovo, 2006). It is considered to have detrimental consequences on the cognitive, physical, psychological, social, emotional and intellectual development of the children hence depriving them of their childhood (Munthali, 2003). International documents such as the Convention on the Rights of the Child (1989) and the ILO Convention No. 182 on the Worst Forms of Child Labour (1999) cogitate child labour as objectionable and injurious to children's total well-being. These documents therefore entreat all state parties to put in much effort towards the eradication of this act of human right abuse and address children's need for protection.

Most scholars in developing countries attribute the high prevalence of child labour to financial exigencies, cultural and social structure (Andvig, Canagarajah \& Kielland, 2001; Basu \& Tzannatos, 2003). There is a global economic downturn in the world today. People are losing their jobs causing lots of hardship. Poverty level is rising each day causing some parents to force their children in labour to supplement their income (UNICEF, 1997). However, this activity or engagement of the children poses lots of danger to them, their families, the community and the nation as a whole.

The child forfeits education to do this work. This work exposes them to health risks and sexual abuse (Abugri, 2005). According to Owusu (2010), these children have a high risk of exposure to social vices.

Obuasi is one of Ghana's mining areas and apart from miners who are given legal permit from the government to operate, people also do shallow mining by illegal means (Galamsey). Young children of school going age are hired to dig the ground, to fetch water and even to look for prospective buyers of the few extracted gold for scanty wage. They do all the menial jobs around the mining milieu. Those who do not work at the mining fields are engaged in street hawking. The work done by these children are at the expense of their education. Children are the future human capital in the country and for that matter they must be educated and trained to occupy and play key roles for development in the near future, instead, they are abandoned to hustle for their upkeep. According to Social Support Foundation (SSF, 2006), an NGO based in Obuasi, Child illegal mining trafficking, is on the increase in Obuasi municipality, children between the ages of seven (7) to fourteen (14) are being transported from the northern part of Ghana to Obuasi to assist in illegal mining or what is popularly termed as 'Galamsey'. This affects their physical, social and psychological well-being as and more 
importantly their schooling. Despite these apparent effects of children's involvement in mining in Ghana, these effects are not well defined by evidence. In fact, no work on the subject as it relates to Ghana has been sighted. It is against this background that this study seeks to explore the effects of child labour on children in the Obuasi Municipality.

\section{Research Methodology}

The study was descriptive in nature. The study adopted the use of the mixed research method. That is the study adopted essentially both qualitative and quantitative methods to collect data for the study. The reason for the choice of this design was to ensure corroboration of the inherent strengths of the qualitative and quantitative approaches to enhance the validity and reliability of the study.

A population is considered to be any group of people, events, or things that are of interest to the researcher and that they wish to investigate (Sekaran, 2000). The target population of the study was all child labourers, their parents, teachers, and the leaders of the "galamsey" pit sites and the processing plant units in Ghana.

The non-probability sampling method was employed in the selection of the sample for the study. Specifically, purposive sampling technique was used to select children who are involved in worst form of child labour, their teachers, parents and leaders at the "galamsey" pit sites and the processing units. This method was used because the choice of the sample for the study was based on the judgment of the researcher which suited the purpose of the study. This technique helped the researcher to purposefully select respondents who can provide the needed information for the study. The power of purposive sampling lies in selecting information rich-cases for in-depth analysis related to the central issues being studied (CEMCA, 2011).

The sample size for this study was fifty (50) people. This consists of 30 children, 5 parents, 5 teachers, 5 "galamsey" leaders and 5 processing plant leaders. The choice of this sample size was to reduce cost, manpower requirements and obtain more comprehensive data from the study population.

Data for the study was collected through questionnaire, observation and interview. Quantitative method was one of the methods to be used in collecting data for the study. It made use of tools such as structured questionnaires which included close ended and open ended questions. The researcher administered the questionnaires by the use of face-toface interview to elicit information from respondents since most of the respondents may be illiterate. This made the researcher explained the questions to the respondents in the language they understand. The questionnaire was also selfadministered to elicit information from those who were literate. This gave them the independence and ability to express themselves without undue interruptions from the researcher.

The study also employed qualitative method to collect data from the field. The research tools to be used under the qualitative methods include direct observation and an interview guide to collect qualitative data from the respondents. The researcher organized in-depth interviews to explore the lived experiences of the respondents.

Data collected from the field were checked for consistency and completeness of responses. The quantitative data were edited, coded and fed into the computer. The Statistical Package for Social Sciences (SPSS) was then used to generate frequency tables, statistical charts and graphs. The qualitative data that is information from the in-depth interview were analyzed thematically and used to support the quantitative data obtained.

\section{Results}

\subsection{Socio-Demographic Characteristics of Respondents}

Table 1: Socio-Demographic Characteristics of Respondents

\begin{tabular}{|c|c|c|}
\hline & Frequency & Percentage \\
\hline Sex & 26 & \\
Male & 4 & 86.7 \\
Female & 30 & 13.3 \\
Total & 14 & 100.0 \\
\hline Marital Status of Parents & 16 & 46.6 \\
Married & 30 & 53.4 \\
Divorced/Separated & 100.0 \\
Total & 11 & 36.6 \\
\hline Educational Background & & \\
\hline Not in School & &
\end{tabular}




\begin{tabular}{|c|c|c|}
\hline Primary & 5 & 16.7 \\
JHS & 14 & 46.7 \\
Total & 30 & 100.0 \\
\hline Residential Status & 27 & \\
Yes & 3 & 90.0 \\
No & 30 & 10.0 \\
Total & & 100.0 \\
\hline
\end{tabular}

Table 1 above presents the socio-demographic profile of the survey participants. As depicted, men constitute around $86.7 \%$ of all survey respondents. With respect to the distribution of the marital status of respondents' parents, it is evident that approximately $53.3 \%$ have parents who were either divorced/ separated while $46.7 \%$ were in the Junior High School (JHS). In terms of the respondents' residential status, the table shows that $90.0 \%$ of the respondents were living with either one or all their parents.

\subsection{Causes of Child Labour}

\subsubsection{Reasons for Respondents' Engagement in Galamsey}

From table 2 below, $36.6 \%$ of the respondents claimed that they engage in galamsey to supplement their family income while $30.0 \%$ indicated that they engage in this activity to get money pay for their educational costs

Table 2: Reasons for Respondents' Engagement in Galamsey

\begin{tabular}{|l|c|c|}
\hline \multicolumn{1}{|c|}{ Reasons } & Frequency & Percent \\
\hline Contribute to family Income & 11 & 36.6 \\
\hline Bear Cost of Education & 9 & 30.0 \\
\hline Meet Basic Needs & 5 & 16.7 \\
\hline N/R & 5 & 16.7 \\
\hline Total & 30 & 100.0 \\
\hline
\end{tabular}

\subsection{Factors that Influenced Respondents to Work}

Table 3 shows that about $73.4 \%$ of the respondents attributed their plight to poverty while $3.3 \%$ of the respondents were influenced by their friends.

Table 3: Factors that Influenced Respondents to Work

\begin{tabular}{|l|c|c|}
\hline \multicolumn{1}{|c|}{ Reasons } & Frequency & Percent \\
\hline Poverty & 22 & 73.3 \\
\hline Home Environment & 7 & 23.3 \\
\hline Friends & 1 & 3.3 \\
\hline Total & 30 & 100.0 \\
\hline
\end{tabular}

Responses from the interview with parents confirm the above findings. A parent exclaimed that:

I have six children and find it difficult meeting their needs so he (the child) does this to help me take care of the family. The money I get from my pure water business is not enough. As for their father, hmmm I don't even know where he is so I single-handedly look after the children.

Another parent also indicated that he is training the child to be able to take over from him when he becomes weak. From table 3 below $63.3 \%$ of the respondents were still in school while the remaining $36.7 \%$ were not in school.

Table 4: Educational Status of Respondents

\begin{tabular}{|c|c|c|}
\hline Variable & Frequency & Percent \\
\hline Yes & 19 & 63.3 \\
No & 11 & 36.7 \\
Total & 30 & 100.0 \\
\hline \multicolumn{3}{|c}{} \\
\hline
\end{tabular}


In order to identify the effects of child labour on the educational attainment of children, the respondents were asked to indicate their performances in the following core subjects before and after their involvement in galamsey.

Table 5: The Performances of the Respondents Before Involving in this Activity

\begin{tabular}{|l|c|c|c|c|}
\hline \multicolumn{1}{|c|}{ Subjects } & $70-100 \%$ & $60-69 \%$ & $50-59 \%$ & $40-49 \%$ \\
\hline Mathematics & 7 & 10 & 2 & - \\
\hline English & - & 6 & 9 & 4 \\
\hline Science & 4 & 11 & 1 & 3 \\
\hline Social Studies & 15 & 4 & - & - \\
\hline
\end{tabular}

Before the children's engagement in galamsey, out of 19 respondents who were in school, 7 indicated that their performance in mathematics was between $70-100 \%, 10$ indicated 60-69\%, while the remaining 2 indicated 50-59\%. From table 5 above, all the 19 respondents believed that their performance in mathematics was above $50 \%$.

In English, 6 respondents indicated that their performance was 60-69\%, 9 indicated 50-59\%, and 4 indicated 4049\%. Cumulatively, 15 out of the 19 respondents indicated that their performance in English was above $50 \%$. In science, 4 indicated 70-100\%, 11 indicated 60-69\%, 1 indicated 50-59\%, and three indicated 40-49\%. Lastly, in social studies, 15 indicated $70-100 \%$ and the remaining 4 indicated $60-69 \%$.

Table 6: The Performances of the Respondents After Involving in this Activity

\begin{tabular}{|l|c|c|c|c|}
\hline \multicolumn{1}{|c|}{ Subject } & $70-100 \%$ & $60-69 \%$ & $50-59 \%$ & $40-49 \%$ \\
\hline Mathematics & - & 3 & 6 & 10 \\
\hline English & - & 1 & 10 & 8 \\
\hline Science & 1 & 4 & 5 & 9 \\
\hline Social Studies & - & 16 & 3 & - \\
\hline
\end{tabular}

From table 6 above, it is clear that after involving in this activity for mathematics 3 respondents indicated $60-69 \%, 6$ indicated $50-59 \%$ and 10 indicated $40-49 \%$; for English one indicated $60-69 \%$, ten indicated 50-59\%, and eight indicated 40-49\%; for Science one indicated $70-100 \%$, 4 indicated $60-69 \%$, five indicated $50-59 \%$, and nine indicated $40-49 \%$; for social studies 16 indicated $60-69 \%$ and three indicated $50-59 \%$.

The respondents were further asked to indicate factors that caused the fall in their performance. From the study, it was clear that absenteeism, lack of parental supervision, health problems and lack of adequate school materials. A respondent indicated that he goes to school at most twice every week. He further stated that this makes him miss classes. Another respondent exclaimed that "I don't get enough time to read and attend classes as I used to do before my engagement in this activity. This has affected my performance in school.

\subsection{Effects of Child Labour on the Social, Economic and Psychological wellbeing of children}

Table 7: Social, Economic, Emotional, Health and Psychological Measures

\begin{tabular}{l|cc}
\hline \multicolumn{1}{c|}{ Measures } & Mean & Standard Deviations \\
\hline I have enough time to rest after every day's activity & 3.50 & 1.81 \\
I cannot associate with my peers due to my involvement in this activity & 3.56 & 1.34 \\
& 3.10 & 1.85 \\
My friends do not relate well with me at school & & \\
I have health problems as a result of my involvement in this activity & 4.65 & 1.48 \\
I cannot concentrate in class & & 1.09 \\
I have been missing classes & 4.33 & 1.77 \\
The activity I engage in is harmful to my physical wellbeing & 4.72 & 0.91 \\
& 3.58 & 1.15 \\
\hline
\end{tabular}


Table 7 shows the descriptive statistics of the effects of child labour on the wellbeing of children. The statement "I have enough rest after every day's activity" has the mean 3.50 which is between 3.50 and 4.49 indicating an agreement. Also, the statement "the activity I engage in is harmful to my physical wellbeing" has a mean of 3.58 .

With respect to the health, the statements "I have health problems as a result of my involvement in this activity" and "I often get sick" had means of 4.65 and 3.48 respectively. The 4.65 is within the 4.50 and above range which is an indication that the respondents strongly agree to the assertion that they have health problems as a result of their involvement in galamsey. The 3.48 also is within the 3.50 to 4.49 range which is an indication of agreement.

In terms of the social wellbeing of the children, the statements "I cannot associate with my peers due to my involvement in this activity" and "My friends do not relate well with me at school" had means of 3.56 and 3.10 respectively. The 3.56 is within the 3.50 and 4.49 range which is an indication that the respondents agree to the assertion that they find it difficult associating with their peers as a result of their involvement in galamsey. The 3.10 also is within the 2.50 to 3.49 range which is an indication of "Not sure".

\section{Discussion}

Findings from the study indicate that the children engaged in galamsey to contribute to their family income, to pay their school fees and to provide for themselves basic needs such as food, clothing, shelter etc. It was further revealed that poverty, home environment, broken home and peer pressure influenced most of the children to engage in galamsey. These findings are consistent with the findings of MESW (2009). MESW (2009) found that the high levels of poverty which are endemic in rural households lead to risky behaviour by household members including children. The most prominent among these risky behaviours as found by MESW (2009) is children's involvement in child labour to supplement household income. Mitesh and Badiwala (2009) re-echoed this by indicating that in deprived communities where child labour is high, children's income contribute significantly towards the upkeep of their homes. UNICEF (2008) also found that poverty undoubtedly contribute to children's engagement in hazardous labour. Poverty deprives the child of the opportunity to make a choice with regards to either going to school or working. The only alternative for children in poor households is to work (UNICEF, 2008).

On the contrary, Odonkor (2007) posits that people's discontent with the educational system due high graduate unemployment, the low quality of education, and inaccessibility to good educational facilities and materials push most parents in the rural communities to engage their children in economic activities to the detriment of their education. Pearce (2009) and ILO and UCW (2010) endorse that educational sector challenges such as inaccessibility to schools and inadequate teachers have a strong relationship with children's involvement in child labour.

Also, it was evident that the children's involvement in this activity has affected them adversely. From the study it was clear that child labour negatively affect the education of children. It was revealed that most of the respondents' academic performance reduced due to their involvement in galamsey. In line with this finding, Heady (2003) found that child labour affect the average number of hours children spend in school. Gibbons et al (2003) augmenting this found child labour to have adverse effect on the completion and retention rate of children in school. They further found that the repetition and dropout rates among working children are very high.

Finally, it was revealed that child labour negatively affects the physical wellbeing and development of children. With respect to the health, it was found that most of the children have health problems such as injuries and illnesses as a result of their involvement in galamsey. In terms of the social life of children, it was clear that the child workers find it difficult relating with their peers. These findings are consistent with findings of the survey conducted by the National Institute for Occupational Safety and Health (1997) which shows a positive relationship between child labour and growth deficiency among children. NIOSH's (1997) survey further shows that child labour has adverse effects on the physical development and wellbeing of children. This finding is supported by Ashagrie's (1998) findings that children involved in child labour are more prone to a variety of work-related health problems, including injuries and illnesses, than adults who perform the same work. A study by Pinder (2000) re-echoes this indicating that a strong relationship exists between child labour and injuries among children.

\section{Recommendations}

Based on the evidence obtained from the study, the following recommendations have been suggested to guide policy decisions that would help reduce the effects of child labour on the development of children.

Firstly, the researcher recommends that parents should be sensitized to show high level of commitment towards 
their children's education to avert involving these children in work which are detrimental to their education and health. Efforts should aim at developing the public awareness of children's rights and how dangerous child labour is to the development of children. Partnership among key stakeholders in the lives of children would go a long way to ensure the success of the awareness creation.

Again, from the study it was revealed that children indulge in galamsey due to family financial exigencies or economic hardship, it is therefore recommended that government and Non-governmental Organisations put in place measures geared towards the maximization of household income. These measures could include the accessibility and sustainability of employment avenues; loans and credit facilities; and employable skills for parents and poor households. This will go a long way to tackle income poverty and material deprivation which will have a trickledown effect on the lives of children in the households.

Moreover, it is also recommended that non-governmental Organisations and Government Agencies should seek to champion the wellbeing of children through inclusive education..

Finally, the powerlessness of children by nature prevents them from fighting for their rights. Hence, the need for human rights activists, social workers as well as other human service workers to engage in rigorous campaign and advocacy for working children. Advocacy against the worst forms of child labour and the promulgation of specific legal framework aimed at addressing this social canker should be one of the major focuses of social workers and policy makers.

\section{Conclusion}

Child workers work at a younger age which makes them susceptible to a prolonged exposure to work, and great vulnerability to hazardous labour. According to this study, families' socio-economic issues such as economic hardship stand out to be the top reasons for which children have to engage in work at a younger age. It is important to note that the galamsey business has several unique features such as high demand of child labourers, easy getting a job, no skills or experience is required, no strict regulations, and easy money that makes it more attractive to children.

The effects of children's engagement in the 'galamsey' business on the total development of children are found to be conspicuous in two areas. One is the interference on children's education and the other is the damage of children's social and physical health due to injuries and sicknesses associated with the work. In sum it can be concluded from the study that child labour has adverse effects on the total development of children and gash the country off its future leaders. The multifaceted nature of the phenomenon requires the involvement of all stakeholders to help address it from the micro to the macro levels to help ensure the holistic development of children.

\section{References}

Abugri, G.S. (2005) The World of child labour, Daily Graphic Features, Wednesday March 23, 2005, p. 7.

Andvig, J. C., Canagarajah, S. \& Kielland, A. (2001). Issues in Child Labor in Africa. Africa Region Human Development Working Paper Series, The World Bank, Human Development Sector Africa Region.

Ashagrie, K. (1998). Statistics on Working Children and Hazardous Child Labour in Brief. Geneva: International Labour Organization.

Basu, K. \& Tzannatos, Z. (2003). The Global Child Labor Problem: What Do We Know and What can We Do?. The World Bank Economic Review, Vol. 17, No. 2, $147-173$.

Convention on the Rights of the Child (CRC), (1989). Geneva: United Nations.

Gibbons, Huebler, \& Loaiza, (2003). Child Labour, Education and the Principle of Non-Discrimination, UNICEF, New York.

Heady, C. (2003). The effect of child labour on learning achievement. World Development, 31(2):385

ILO, (1999). Convention 182 \& 138: Convention on the Worst Forms of Child Labour. Geneva, International Labour Organization.

ILO and UCW (2010). Child labour: trends challenges and policy responses. Joining forces against child labour. Inter-agency report for The Hague Global Child Labour Conference of 2010, International Labour Organisation (ILO) and Understanding Children's Work (UCW) Programme -Geneva: ILO, 2010. pp.83-97.

Kelland, A. \& Tovo, M. (2006). Children at Work: Child Labour Practices in Africa. London: Lynne Rienner Publishers.

Ministry of Employment and Social Welfare (MESW), (2009). National Plan of Action (NPA) for the elimination of the worst forms of child labor in Ghana(2009-2015), MESW, Accra, November 2009.

Munthali, A. (2003). Hunger, Public Policy and Child Labour: Case Study of Malawi, Lilongwe: IPEC Programme Final Report.

NIOSH, (1997). Child Labour Research Needs: Recommendations from the National Institute for Occupational Safety and Health, US Department of Health and Human Services and CDC. Retrieved from http://www.cdc.gov/niosh/97-143a.html on 2/03/12.

Odonkor, M. (2007).Addressing child labour through education: A study of alternative/ complementary initiatives in quality education delivery and their suitability for cocoa -farming communities. Geneva: International Cocoa Initiative (ICI). http://www.cocoainitiative.org/images/stories/pdf/ici_reports/education_initiatives_final_report.pdf (Accessed 11/11/2013). 
Pearce, C. (2009). From closed books to open doors-West Africa's literacy challenge: Oxfam.

Pinder, A. D. J. (2000). Manual Handling in the Brick Production Industry: Results of a Study of the Ergonomics of Brick Packing, Health \& Society Laboratory: Human Factors Group, UK.

Scrumpf, E. (2004). Child Labour in the West. Encyclopedia of Children and Childhood History in History and Society. Retrieved from http://www.faqs.org/ on 02/03/2012.

Sekaran, U. (2000). Research methods for business. New York: John Wiley \& Sons, Inc.

UNICEEF, (1997). The State of the World's Children: Focus on child labour. UNICEF.

UNICEF (2008). Child protection from violence, exploitation and abuse. http://www.unicef.org/protection/index_childlabour.html (Accessed on 25/09/2013). 
